\title{
Superpigs go to market
}

\section{Sydney}

THE Australian government is under pressure to introduce new laws to govern the regulation of genetic engineering after a public outcry over the sale for human consumption of 53 genetically altered pigs. The pigs had come from a research programme aimed at breeding 'superpigs' through the introduction of extra copies of the gene for porcine growth hormone. They were sold for slaughter apparently without approval from any of the bodies regulating genetic engineering.

At present, guidelines on genetic engineering in Australia are issued by the federal government's Genetic Manipulation Advisory Committee (GMAC). Any organization seeking to release a genetically altered organism into the environment is expected to seek advice from GMAC, although compliance with the guidelines is voluntary.

Metrotec Pty Ltd was responsible for the experiments with the pigs. The 53 pigs they sent to the slaughterhouse were the offspring of a transgenic boar not expressing the gene and had been removed from the programme because their growth hormone gene was not functional. The company is part owned by the University of Adelaide, but the university's Institutional Biosafety Committee had not assessed the dangers of releasing the pigs.

Barry Lloyd, managing director of Metrotec, said on ABC Radio that while the university is required to conform to the guidelines on genetic engineering, private companies are not.

Metrotec further argues that the pigs were released with the knowledge of both state and federal government bodies. John Smeaton, a director of Metrotec, says that the National Health and Medical Research Council and the South Australian Health Commission had approved the meat for consumption. Smeaton also says that the release of the pigs had been

\section{Correction: Dounreay}

Thomas Robertson of the Hahn Meitner Institute (HMI) was misquoted in the article "Waste issue threatens reactor" on 10 May (Nature 345 , $105 ; 1990)$ as saying that fuel from a West Berlin research reactor is not kept separate from nuclear bomb material at the Dounreay facility in Britain; HMI has since been assured that spent fuel from HMI would not be reused for military purposes at Dounreay.

\section{Correction: In vitro fertilization:}

AN editing error in last week's news item on an MRC study on IVF (Nature 345, 283; 1990) changed the meaning of the last sentence, which should read: "In the opinion of Brian Lieberman, from St Mary's Hospital in Manchester, improved preservation of frozen embryos over the next two or three years should mean that multiple births will be less common discussed with Brian Booth, a representative of the Recombinant DNA Monitoring Committee, the precursor to GMAC.

According to Lorne Skene, project manager of the genetic manipulation section of the Victorian Law Reform Commission, GMAC has no powers of direct sanction should their guidelines be ignored. GMAC can, however, recommend the removal of federal funding and tax incentives from both the research group involved and the parent institution.

The Australian Conservation Foundation (ACF) is taking advantage of the questions raised by release of the pigs to push for a national uniform system of legal regulation. Phillip Toyne, director of ACF, said: "As companies increasingly seek to commercialize research results new laws are becoming even more necessary." The University of Adelaide also believes GMAC guidelines should become enshrined in legislation. "This would ensure that all organizations operating in this area would be required to meed defined standards", the university registrar said in a public statement.

In a report released last year, the Victorian Law Reform Commission recommended legislation requiring mandatory notification of any proposed release of a genetically altered organism to GMAC and to any relevant state or federal body, such as the Department of Agriculture.

The commission also called for an environmental assessment before the release of any experimental organisms and the advertising of proposed releases "to ensure that interested people can obtain information and participate in decision-making before the proposal is approved". Australia's 'superpigs' were the world's first transgenic animals with enhanced production characteristics. In a project run by Bob Seamark, reader in endocrinology at the University of Adelaide, transgenic pigs incorporating genes for porcine growth hormone grew as much as 17 per cent faster, with a 30 per cent better feed conversion rate.

Seamark says he is against the introduction of legislation, "because it is inflexible and irreversible, [and] could close down the whole of recombinant research in one act of parliament. The solution is to develop confidence in researchers who abide by voluntary guidelines. They are not a bunch of naive wackers doing strange and evil things." Metrotec, however, would welcome legislation. "We would be happy with a stable set of rules to which we would have some input. We don't want to invest five years work into these animals only to have someone reinterpret the voluntary quidelines and say we can't market the pigs", Smeaton says.

Tania Ewing
Gorbachev leads silicon summit

\section{Washington}

Soviet President Mikhail Gorbachev and other Soviet officials will visit Stanford University and research centres in Silicon Valley in California next week to lay the groundwork for a similar science and hightechnology oasis near Moscow. The visit will begin a ten-day meeting between the two countries to establish trade relations, with the aim of encouraging US companies to participate in a 'Soviet Silicon Valley' in the city of Troitsk, near Moscow.

Known as the Soviet Silicon Summit, the meeting will follow the Bush-Gorbachev summit at which the United States is expected to grant the Soviet Union 'most favored nation' status. US officials have also declared their intention to lift many of the restrictions imposed by the Coordinating Committee on Multilateral Export Controls (COCOM) on the sale of hightechnology products to the Soviet Union.

Although Gorbachev is expected to spend only one day at Stanford, visiting the university and meeting Silicon Valley business leaders, other Soviet officials will stay to tour the area's laboratories and production facilities. Next week, the officials are expected to unveil plans to convert Soviet military technologies to commercial use in fields such as microelectronics and communications.

As part of their drive to beat swords into microchips, Soviet officials have recently signed an agreement with Bechtel International, a large US engineering company, to study the feasibility of developing a 'technopolis' near Troitsk, which is already home to the Kurchatov Institute of Atomic Energy. The Troitsk Research Development Project aims to attract international businesses to help develop and invest in Soviet advances in fields such as nuclear fusion and laser technology.

The Soviet Union is expected to spend about $\$ 100$ million a year to support the project. If plans are approved, Bechtel will eventually build conference centres, a new international airport and an advanced telecommunications network in Troitsk by the year 2020. By that time, Troitsk, which at present has a population of 30,000 , is expected to have a population of over 100,000 .

During the Silicon Valley summit, to be held from 4 to 14 June in Santa Clara, California, Soviets will meet US companies interested in a range of business connections. The 15-member Soviet delegation is the largest to visit the United States to forge ties with US high-technology companies. After the meeting, the Soviets will open a full-time Silicon Valley sales office featuring demonstrations of Soviet software, Soviet market research data and a research library.

G. Christopher Anderson 